\title{
Microbiological and cytological characterization of coelomic fluid from three captive endangered amphibian Gastrotheca species with edema syndrome: preliminary analysis
}

\author{
Anahí Oleas-Paz ${ }^{1}$, Ana Cecilia Santamaría-Naranjo², Maira Rojas-Carrillo², Andrés Merino-Viteri ${ }^{3}$
} and Alexander Genoy-Puerto ${ }^{1 *}$ (1)

\begin{abstract}
Objective: Edema syndrome is highly prevalent but under researched in captive frogs around the world. The objective of the present study was to characterize at a basic microbiological and cytological level of the bacteria of the edema fluid of 20 individuals of the genus Gastrotheca to determine the presence of possible anaerobic and aerobic bacteria.

Results: Fourteen types of bacteria were identified in the edema fluid, 12 of them at the species level (Pasteurella haemolytica, Hafnia alvei, Enterobacter agglomerans, Aeromonas hydrophila, Pseudomonas fluorescens, Burkholderia pseudomallei, Salmonella arizonae, Enterobacter gergoviae, Enterobacter sakazakii, Yersinia enterocolitica, Klebsiella oxytoca, and Klebsiella ozaenae) and two at the genus level (Enterococcus spp. and Streptococcus spp.). The most frequently identified cells were lymphocytes (37.7\% in females and $46.4 \%$ in males), erythrocytes (23.5\% in females and $17.5 \%$ in males) and neutrophils ( $4.2 \%$ in females and $2.8 \%$ in males). Finally, no relationship was found between the data obtained and the sex of the individuals studied.
\end{abstract}

Keywords: Marsupial frogs, Edema fluid, Klebsiella ozaenae, Burkholderia pseudomallei, Enterococcus sp.

\section{Introduction}

Amphibians are distributed worldwide in different ecosystems. However, there is currently a marked decline in the amphibian population [1-3]. Ecuador is one of the countries that faces this decline [4], and the Gastrotheca genus is one of the threatened amphibian genera [5-7].

\footnotetext{
*Correspondence: alexandergenoy@gmail.com

${ }^{1}$ Escuela de Medicina Veterinaria, Facultad de Ciencias de la Salud, Universidad de Las Américas, Vía Nayón S/N, 170503 Quito, Pichincha, Ecuador

Full list of author information is available at the end of the article
}

Because of this decline, in Ecuador, conservation projects have been developed to mitigate the decline. The "Balsa de Sapos" Conservation Initiative is one of those projects. A large number of amphibian species in captivity has led to the realization of scientific studies concerning pathologies and diagnostics of diseases, such as edema syndrome $[8,9]$.

Edema syndrome is a disease that affects innumerable amphibian species and has a high prevalence among frogs in captivity $[10,11]$. Causes of edema syndrome vary from bacterial septicemia and fungal or viral infection to metabolic disorders and dietary and husbandry deficiencies [9, 10, 12-17]. Clinical microbiology approaches, as

(c) The Author(s) 2019. This article is licensed under a Creative Commons Attribution 4.0 International License, which permits use, sharing, adaptation, distribution and reproduction in any medium or format, as long as you give appropriate credit to the original author(s) and the source, provide a link to the Creative Commons licence, and indicate if changes were made. The images or other third party material in this article are included in the article's Creative Commons licence, unless indicated otherwise in a credit line to the material. If material is not included in the article's Creative Commons licence and your intended use is not permitted by statutory regulation or exceeds the permitted use, you will need to obtain permission directly from the copyright holder. To view a copy of this licence, visit http://creativeco mmons.org/licenses/by/4.0/. The Creative Commons Public Domain Dedication waiver (http://creativecommons.org/publicdomain/ zero/1.0/) applies to the data made available in this article, unless otherwise stated in a credit line to the data. 
applied in this study, improve the knowledge and management of this health problem in captive amphibian populations.

The following study presents initial microbiological and cytological characterizations of the edema fluid of individuals of the genus Gastrotheca from the "Balsa de Sapos" Conservation Initiative of the Pontificia Universidad Católica del Ecuador. The species studied were Gastrotheca (G.) litonedis, Gastrotheca riobambae and Gastrotheca pseustes, all of which are endemic to Ecuador and assigned to different categories of extinction risk $[5,6]$.

This study helps to improve the health management of the animals in this institution and to provide the information needed to create health management plans in captive breeding institutions.

\section{Main text \\ Methods}

During the time of the study (3 months), the number of individuals was limited by the presence or absence of the syndrome, only anurans of Gastrotheca genus had edema syndrome in the institution. Samples were taken from live animals with the syndrome to prevent contamination by autolysis process. Ten males and ten females, with representatives of G. litonedis (ten), G. pseustes (eight) and G. riobambae (two). All animals had obvious edematous swelling in the coelomic cavity, with expansion through their subcutaneous tissue into the arms and legs (Fig. 1a).

All animals lived in captivity, but $85 \%$ of the frogs were collected from natural habitats in Ecuador in the provinces of Imbabura, Cotopaxi, Tungurahua, Chimborazo, Cañar, and Azuay between 2007 and 2010. One individual was provided by the Amaru Zoo in Cuenca in 2009, and the remaining $15 \%$ were born in the center in 2007, 2009 and 2010. The animals lived in terrariums that contained a substrate made by dried leaves and dirt that were collected from the jungles located in the Ecuadorian Amazon and autoclaved monthly. The humidity was approximately $60-80 \%$, and the temperature inside the terrarium varied from 20 to $22{ }^{\circ} \mathrm{C}$. The animals were given only water filtered with 20-in. thread, washable polyester, and activated charcoal and exposed to UVB (ultraviolet B) light.

\section{Sampling}

The sampling, handling and preservation of edema fluid from the coelomic cavity was based on descriptions provided in specific literature [18, 19] (Fig. 1b). The animal was placed in dorsal recumbency with a level decline in the cranial direction. The para-medial region was cleaned with diluted chlorhexidine. In that region, an insulin needle was inserted, $1 \mathrm{ml}$ of the liquid was extracted, the needle was carefully removed, and a small pressure was generated in the area with sterile gauze. The sample was divided into two aliquots $(0.4 \mathrm{ml}$ each) for microbiological and cytological characterization. All samples were transported in refrigerated conditions and immediately processed in the Laboratory of Microbiology of the Universidad de Las Américas.

\section{Microbiological analysis}

The materials and methods needed for the analysis of samples were based on similar studies or studies of other species [11, 20-22]. The portion for microbiological characterization was inoculated into tubes containing thioglycolate and resazurin for transport to the laboratory. Incubation was performed at $37{ }^{\circ} \mathrm{C}$ in an aerobic environment. Bacteria were isolated on Bi Plate Blood MacConkey agar, and the following laboratory tests were performed: Gram stain (Merck ${ }^{\circledR}$, Germany), catalase (Mediquin ${ }^{\circledR}$, Ecuador), oxidase (Hardy Diagnostics ${ }^{\circledR}$, USA), bile-esculin (HiMedia Laboratories ${ }^{\circledR}$, India) and Microgen ID (Microgen Bioproducts Ltd. ${ }^{\circledR}$, United Kingdom).

\section{Cytological analysis}

Two smears of the edema fluid per animal were stained using the hematoxylin-eosin staining technique [23]. Subsequently, cell counting and analysis of the characteristics of the cells were performed [11, 24].

\section{Statistical analysis}

The program Minitab ${ }^{\circledR}$ 17.1.0 was used to obtain the mean, standard deviation and differences in cell type. The Mann-Whitney test was used to determine any significant differences between males and females.

\section{Results}

\section{Microbiology}

Fourteen bacteria were obtained from 12 amphibians (Table 1); 78\% were gram-negative bacilli (Pasteurella haemolytica, Hafnia (H.) alvei, Enterobacter agglomerans, Aeromonas (A.) hydrophila, Pseudomonas (P.) fluorescens, Burkholderia pseudomallei, Salmonella arizonae, Klebsiella ozaenae, Klebsiella oxytoca, Enterobacter gergoviae, Enterobacter sakazakii, and Yersinia enterocolitica), and $22 \%$ were gram-positive cocci (Streptococcus spp. and, Enterococcus spp.). The bacterial growth of the samples from females was mostly pure cultures, while most of the samples from males exhibited mixed growth.

\section{Cytology}

Approximately $30 \%$ of the total analyzed samples did not show cellular components, while the remaining $70 \%$ did. Normal morphology of some identified cells could be seen, and some reactive neutrophils were observed 
(Fig. 1c-d). Similarly, phagocyte vacuoles were observed in the leukocytes of one individual (Fig. 1e). No other type of cells, such as mesothelial cells, were found.

The cells observed in females and males did not exhibit significant differences between the relationship of the cell count and the sex of the individual. Females had higher values of erythrocytes, neutrophils, basophils, and monocytes than males. On the other hand, males had higher values of eosinophils, lymphocytes, and thrombocytes (Table 2).

\section{Discussion}

\section{Microbiology}

When evaluating a bacterial infection, it must be considered that the presence of bacteria in a culture does not always indicate disease since these can be bacteria of the individual's normal microbiota [25, 26].

Most bacterial septicemias are caused by aerobic gramnegative bacteria, although there are some reports of septicemia caused by gram-positive bacteria [13]. This statement coincides with the findings of the present

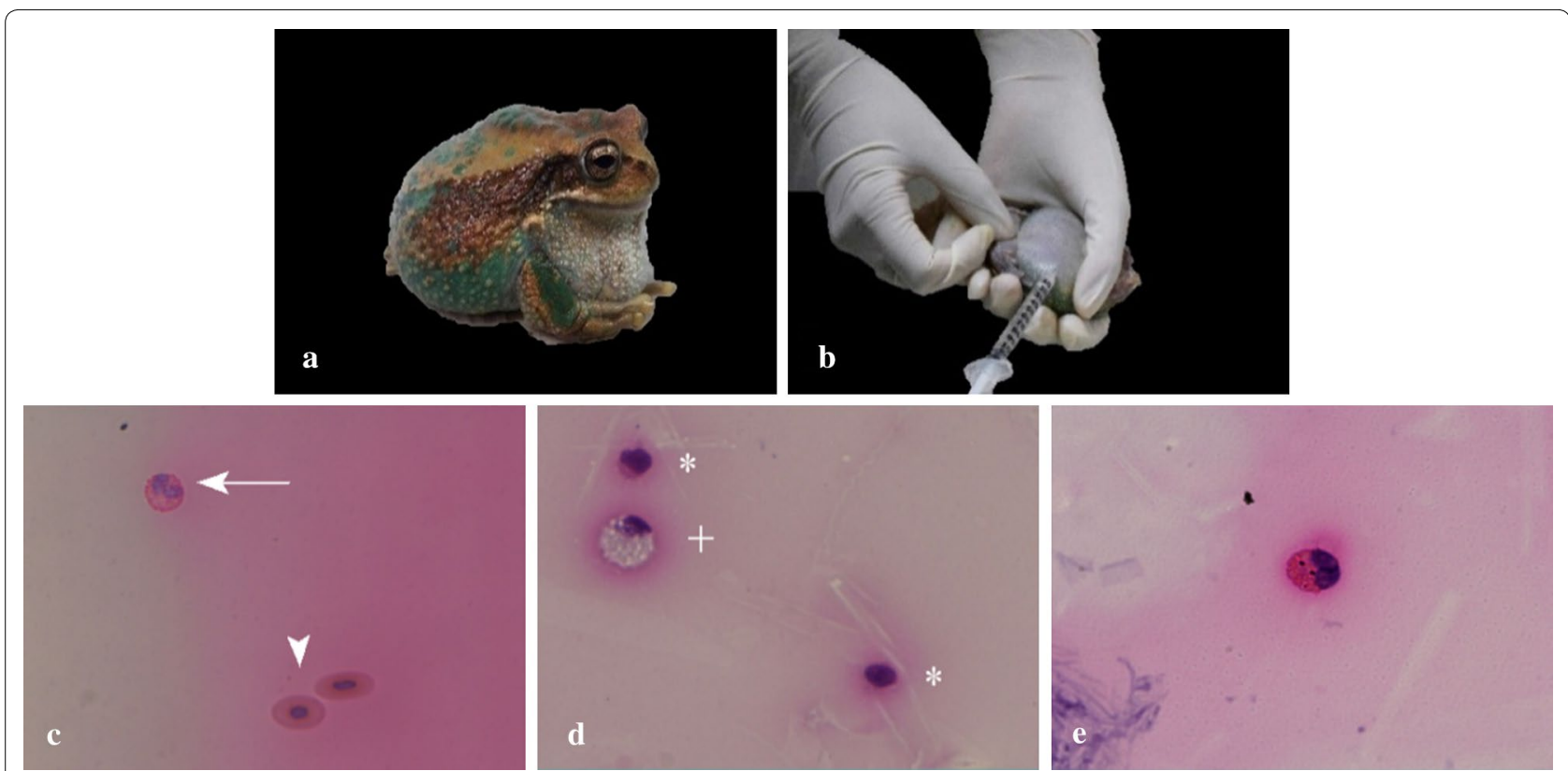

Fig. 1 Edema, sampling and morphology of edema fluid cells. Gastrotheca riobambae with edema in the coelomic cavity, legs, and arms (a). Position of animal in dorsal recumbency for sampling of edema fluid (b). Photomicrographs of the cells observed: erythrocytes (arrowhead) and eosinophils (arrow) (c), reactive neutrophils (plus sign) and lymphocytes (asterisks) (d) and neutrophils with endocytic vesicles visible inside the cytoplasm (e). Slides were stained with H\&E, $\times 400$ for $\mathbf{c}-\mathbf{e}$

Table 1 Gram stain characteristics and macroscopic aspects of bacteria isolated from Gastrotheca species

\begin{tabular}{|c|c|c|c|}
\hline Sex/species & Isolates & $\begin{array}{l}\text { Gram stain } \\
\text { Positive or negative }\end{array}$ & $\begin{array}{l}\text { Gram stain } \\
\text { Morphotypes }\end{array}$ \\
\hline \multirow[t]{4}{*}{ Female $G$. litonedis $(n=4 / 10)$} & Pasteurella haemolytica & - & Bacilli \\
\hline & Hafnia alvei & - & Bacilli \\
\hline & Enterobacter agglomerans & - & Bacilli \\
\hline & Aeromonas hydrophila/Pseudomonas fluorescens & $-/-$ & Bacilli/Bacilli \\
\hline \multirow[t]{2}{*}{ Male G. litonedis $(n=2 / 10)$} & Streptococcus & + & Cocci \\
\hline & Burkholderia pseudomallei/Salmonella arizonae & $-/-$ & Bacilli/Bacilli \\
\hline \multirow[t]{2}{*}{ Female G. pseustes $(n=2 / 8)$} & Klebsiella ozaenae & - & Bacilli \\
\hline & Enterobacter gergoviae/Enterococcus spp. & $-/+$ & Bacilli/Cocci \\
\hline \multirow[t]{2}{*}{ Male G.pseustes $(n=2 / 8)$} & Enterobacter sakazakii/Enterococcus spp. & $-/+$ & Bacilli/Cocci \\
\hline & Yersinia enterocolitica & - & Bacilli \\
\hline \multirow[t]{2}{*}{ Male G. riobambae $(n=2 / 2)$} & Klebsiella oxytoca/Enterococcus spp. & $-/+$ & Bacilli/Cocci \\
\hline & Klebsiella ozaenae/Burkholderia pseudomallei & $-/-$ & Bacilli/Bacilli \\
\hline
\end{tabular}


Table 2 Erythrocyte and leukocyte series of edema fluid from 20 individuals of the genus Gastrotheca

\begin{tabular}{lcc}
\hline Cell type (\%) & Females $(\mathbf{n}=\mathbf{1 0})$ & Males $(\mathbf{n}=\mathbf{1 0})$ \\
\hline Erythrocytes & $23.5 \pm 27.7(0.0-73.0)$ & $17.5 \pm 24.1(0.0-61.0)$ \\
Neutrophils & $4.2 \pm 4.7(0.0-13.5)$ & $2.8 \pm 3.9(0.0-12.5)$ \\
Eosinophils & $0.5 \pm 0.7(0.0-2.0)$ & $1.6 \pm 2.3(0.0-7.0)$ \\
Basophiles & $2.5 \pm 5.4(0.0-17.5)$ & $0.4 \pm 0.8(0.0-2.5)$ \\
Lymphocytes & $37.7 \pm 31.4(0.0-80.5)$ & $46.4 \pm 36.9(0.0-91.0)$ \\
Monocytes & $0.3 \pm 0.4(0.0-1.0)$ & $0.1 \pm 0.2(0.0-0.5)$ \\
Thrombocytes & $1.4 \pm 1.5(0.0-4.0)$ & $1.5 \pm 1.1(0.0-3.0)$ \\
\hline
\end{tabular}

Values are expressed as the mean \pm standard deviation (minimum-maximum)

study, in which $78 \%$ of the bacteria identified were gram negative and the remaining $22 \%$ were gram positive.

The potentially pathogenic bacteria identified agree with those detailed in the literature on amphibians: Streptococcus [27], Klebsiella spp. [14, 27], H. alvei [27, 28], Pseudomonas spp. [10, 27], Enterobacter spp. [22], A. hydrophila [15, 29], Salmonella spp. [30], and Enterococcus spp. [31]. However, not all bacteria detected have pathogenic potential. A previous study detected cultivable bacteria in G. riobambae and G. plumbea associated with the skin of these frogs in Ecuador and found several isolates with known anti-Bd activity (P. fluorescens and $A$. hydrophila) and other genera and species similar to those reported in our study (e.g., Enterobacter spp., Burkholderia cepacia, Pseudomonas palleroniana and Aeromonas veronii) [32].

Although most of the bacteria in the present study have been described as typical of the amphibian microbiota, they could be part of a secondary infection caused by a primary viral or fungal infection [11, 22, 26, 27]. A. hydrophila, Pseudomonas spp. and Streptococcus spp. have been identified as the cause of red-leg syndrome [33].

\section{Cytology}

In the case of the genus Gastrotheca, cytology reference values do not exist. Additionally, the morphology of the cells varies between anuran species and is usually compared to that of other vertebrates [11, 24,34,35].

It is necessary to mention that in amphibians, knowledge of the response of the leukocyte series to diseases is limited, partly because leukocyte evaluation is not a routine methodology used in anurans [34] and because the cells identified in the edema fluid samples came from a blood extravasation, not from peripheral blood [36].

Studies show that the red blood cell count in females is lower than that in males and that the leukocyte count is uniform [37]. In general, normal cytology values and values with variations derived from pathologies can be influenced by sex [38]. In this case, females had a higher percentage of erythrocytes, neutrophils, basophils, and monocytes, and males had a higher percentage of lymphocytes and eosinophils; however, no relationship was found between the statistical results analyzed and the sex of the individuals.

The basophil count was low; these cells play a similar function to those mammals because they are peroxidase positive and have hydrolytic enzymes [34]. Similarly, thrombocytes were found in small quantities, and these cells have a function comparable to the function of those of reptiles and birds [24, 39]. Eosinophils also exhibited low counts; these cells are active in parasitic infections or in polluted areas [40,41], but they have an inferior phagocytosis ability [34]. These low numbers are observed even in noninflammatory effusions, where there are low counts of mesothelial cells, macrophages, granulocytes, and lymphocytes [11].

Neutrophils and monocytes of amphibians share similar characteristics of migration and phagocytic activity and have the same enzymes that occur in the same cells of other vertebrates, and an increased count suggests an inflammatory response [34]. Only neutrophils are present in high numbers in both sexes of Gastrotheca.

B lymphocytes are capable of phagocytosis in response to bacterial infections [42]. In the present study, it was possible that there was a relationship between the results obtained in the microbiological characterization and the lymphocytosis and neutrophilia observed due to the presence of bacteria.

Likewise, a study carried out on individuals from the herpetofauna of Turkey determined that $80 \%$ of the leukocytes present in peripheral blood were lymphocytes and monocytes [43]. These results are partially compatible with the results regarding lymphocytes of our study. Their presence is related to an excitement response, stimulation of the immune system, or possibly lymphoid leukemia [34].

Despite the presence of the bacteria and types of cells in this study, all the animals did not show evidence or clinical signals congruent with infectious disease. In this case, it may be a consequence of captive management; since amphibians are demanding in terms of environmental and nutritional requirements, those factors most likely increased the number of bacteria but did not cause disease or death. Systemic bacterial infections are common in debilitated, stressed, or crowded amphibians [11].

One kind of effusion fluid type is septic exudate within phagocytes [21]. In amphibians and reptiles, the inflammatory response depends on the temperature and is classified according to the predominant cell type [39]. In addition, if phagosomes or vacuoles from phagocytosis are observed in leukocytes due to 
phagocytosis of bacteria, septic inflammation is considered [40]. In contrast, samples with higher total protein $(>3 \mathrm{~g} / \mathrm{dl})$ and cell counts $(>7000 / \mathrm{ml})$ are likely exudates, and inflammatory conditions should be considered [11]. A unique sample was observed with one phagosome, but it is necessary to add information such as specific gravity, total protein, and cell count to categorize the type of cavity fluid.

Another type of fluid is the transudate type that most likely derives from metabolic imbalance, such as hypoproteinemia [44]. The increase in solute attracts solvent, in this case, water, which leads to a weight increase. Here, it is possible to consider edema as a chronic process, which facilitates the passage of water over a large time period and, consequently, an increase in weight and abdominal fluid with low densities.

It is important to understand that edema syndrome has a strong relation to a deficit in osmoregulation, which could be caused by many pathogens and failure of a variety of body systems, causing difficulty in antemortem diagnosis [9]. In this study, the cause of edema was most likely related to a fusion of chronic osmoregulation failure and pathogens. Other causes of edema are a low solute concentration in water or acute renal disease (captivity) [45]. Thus, additional studies on the level of management and pathology are necessary to complement a microbiological and cytological characterization of this problem in captive anurans.

\section{Limitations}

The literature on the normal microbiota and cytological characteristics of marsupial frogs is limited. The design of this study is adequate only for a preliminary investigation since complementary approaches will be necessary as: characterization of other potential microorganism as virus or fungi, physicochemical characterization of fluid, if possible samples of fluid coelomic and comparison of blood parameters of non-diseased animals, and sequencing of the isolated bacteria.

\section{Abbreviations}

G: Gastrotheca; UVB: ultraviolet B; H: Hafnia; A: Aeromonas; P: Pseudomonas.

\section{Acknowledgements}

We are grateful to Balsa de los Sapos Conservation Initiative personnel for logistics and methodological support, to Biological and Chemical Sciences Laboratories, and to the Investigation Laboratories (UDLA) and both technician teams for support in all investigation stages.

\section{Authors' contributions}

AOP and AGP: contributions to conception, personnel coordination and design, and writing. AOP, ACSN, MRC, AMV, and AGP: contribution to the acquisition of data and critically revising the manuscript. AOP, ACSN, and MRC: critical contribution to analysis and interpretation of data. All authors read and approved the final manuscript.

\section{Funding}

This work was funded by VET.AG.17.04 and VET.AG.18.02 Grants from Directorate-General for Research of the Universidad de Las Américas (UDLA), Quito, Ecuador. Also was funded by the General Academic Direction at Pontificia Universidad Católica del Ecuador through the K13039 and L13039 research projects. These funding bodies did not participate in the design of the study and collection, analysis, and interpretation of data and in writing the manuscript.

\section{Availability of data and materials}

All relevant data are included in the manuscript.

\section{Ethics approval and consent to participate}

The study was conducted according to the requirements for animal welfare accepted by the Universidad de Las Américas (UDLA) and Balsa de los Sapos Conservation Initiative (Pontificia Universidad Católica del Ecuador). The captivity and management conditions were approved and evaluated by the Ecuadorian Environmental Ministry (MAE) through the patent for wildlife management 2017 No007-207-FAU-DPAP-MA and Framework Contract for Access to Genetic Resources assigned the number MAE-DNB-CM-2019-0112.

\section{Consent to publish}

Not applicable.

\section{Competing interests}

The authors declare that they have no competing interests.

\section{Author details}

${ }^{1}$ Escuela de Medicina Veterinaria, Facultad de Ciencias de la Salud, Universidad de Las Américas, Vía Nayón S/N, 170503 Quito, Pichincha, Ecuador. ${ }^{2}$ Laboratorios Multidisciplinarios de Ciencias Biológicas y Químicas, Universidad de Las Américas, De Los Colimes y Avenida de los Granados, 170125 Quito, Pichincha, Ecuador. ${ }^{3}$ Museo de Zoología (QCAZ), Escuela de Ciencias Biológicas, Pontificia Universidad Católica del Ecuador, Av. 12 de Octubre 1076 y Roca, 170523 Quito, Pichincha, Ecuador.

Received: 6 September 2019 Accepted: 6 December 2019

Published online: 16 December 2019

\section{References}

1. Blaustein AR, Kiesecker JM. Complexity in conservation: lessons from the global decline of amphibian populations. Ecol Lett. 2002;5(4):597-608.

2. Whiles MR, Hall RO Jr, Dodds WK, Verburg P, Huryn AD, Pringle CM, et al. Disease-driven amphibian declines alter ecosystem processes in a tropical stream. Ecosystems. 2013;16(1):146-57.

3. Daszak P, Cunningham AA, Hyatt AD. Infectious disease and amphibian population declines. Divers Distrib. 2003;9(2):141-50.

4. Menéndez-Guerrero PA, Graham CH. Evaluating multiple causes of amphibian declines of Ecuador using geographical quantitative analyses. Ecography. 2013;36(7):756-69.

5. IUCN SSC Amphibian Specialist Group 2019. Gastrotheca litonedis. The IUCN Red List of Threatened Species 2019. 2019;e.T55342A98647315.

6. IUCN SSC Amphibian Specialist Group 2018. Gastrotheca pseustes. The IUCN Red List of Threatened Species 2018. 2018;e.T55354A98647595.

7. Pessier AP, Baitchman EJ, Crump P, Wilson B, Griffith E, Ross H. Causes of mortality in anuran amphibians from an ex situ survival assurance colony in Panama. Zoo Biol. 2014;33(6):516-26.

8. Hadfield CA, Whitaker BR. Amphibian emergency medicine and care. Semin Avian Exot Pet Med. 2005;14(2):79-89.

9. Pessier AP. Edematous frogs, urinary tract disease, and disorders of fluid balance in amphibians. J Exot Pet Med. 2009;18(1):4-13.

10. Cecil TR. Amphibian renal disease. Vet Clin N Am Exot Anim Pract. 2006;9(1):175-88.

11. Pessier AP. Cytologic diagnosis of disease in amphibians. Vet Clin N Am Exot Anim Pract. 2007;10(1):187-206.

12. Wright KM. Idiopathic Syndromes. In: Wright KM, Whitaker BR, editors. Amphibian medicine and captive husbandry. Malabar: Krieger Publishing Company; 2001. p. 239-44. 
13. Heinz-Taheny KM. Cardiovascular physiology and diseases of amphibians. Vet Clin N Am Exot Anim Pract. 2009;12(1):39-50.

14. Schumacher J. Selected Infectious diseases of wild reptiles and amphibians. J Exot Pet Med. 2006;15(1):18-24.

15. Pessier AP, Mendelson III JR. A manual for control of infectious diseases in amphibian survival assurance colonies and reintroduction programs. Ver. 2.0. Apple Valley: IUCN/SSC Conservation Breeding Specialist Group; 2017.

16. Densmore $\mathrm{CL}$, Green DE. Diseases of amphibians. ILAR J. 2007:48(3):235-54.

17. Vaughan RJ, Vitali SD, Payne KL, Eden PA. A splendid tree frog with edema syndrome and intestinal adenocarcinoma. Vet Clin N Am Exot Anim Pract. 2006:9(3):583-7.

18. Stacy $\mathrm{NI}$, Hollinger C. Chapter 4-Introduction to comparative clinical pathology. In: Terio KA, McAloose D, Leger JSBT-P of W and ZA, editors. Academic Press; 2018. p. 55-115.

19. Whitaker BR. Clinical Techniques. In: Wright KM, Whitaker BR, editors. Amphibian medicine and captive husbandry. Malabar: Krieger Publishing Company; 2001. p. 89-110.

20. Campbell TW. Basics of cytology and fluid cytology. Vet Clin N Am Exot Anim Pract. 2007;10(1):1-24.

21. Alleman AR, Kupprion EK. Cytologic diagnosis of diseases in reptiles. Vet Clin N Am Exot Anim Pract. 2007;10(1):155-86.

22. Pasteris SE, Bühler MI, Nader-Macías ME. Microbiological and histological studies of farmed-bullfrog (Rana catesbeiana) tissues displaying red-leg syndrome. Aquaculture. 2006;251(1):11-8.

23. Dey P. Haematoxylin and eosin stain of the tissue section. In: Dey P, editor. Basic and advanced laboratory techniques in histopathology and cytology. Singapore: Springer; 2018. p. 69-79.

24. Claver JA, Quaglia AIE. Comparative morphology, development, and function of blood cells in nonmammalian vertebrates. J Exot Pet Med. 2009;18(2):87-97

25. Sheafor B, Davidson EW, Parr L, Rollins-Smith L. Antimicrobial peptide defenses in the salamander, Ambystoma tigrinum, against emerging amphibian pathogens. J Wildl Dis. 2013;44(2):226-36.

26. Klaphake E. Bacterial and parasitic diseases of amphibians. Vet Clin N Am Exot Anim Pract. 2009;12(3):597-608.

27. Montel Mendoza G, Pasteris SE, Ale CE, Otero MC, Bühler MI, NaderMacías MEF. Cultivable microbiota of Lithobates catesbeianus and advances in the selection of lactic acid bacteria as biological control agents in raniculture. Res Vet Sci. 2012;93(3):1160-7.

28. Reavill DR. Amphibian skin diseases. Vet Clin N Am Exot Anim Pract. 2001;4(2):413-40.

29. Clayton LA, Gore SR. Amphibian emergency medicine. Vet Clin N Am Exot Anim Pract. 2007;10(2):587-620.

30. Briones V, Téllez S, Goyache J, Ballesteros C, Del Pilar Lanzarot M, Domínguez L, et al. Salmonella diversity associated with wild reptiles and amphibians in Spain. Environ Microbiol. 2004;6(8):868-71.
31. Rana SW, Kumar A, Walia SK, Berven K, Cumper K, Walia SK. Isolation of Tn1546-like elements in vancomycin-resistant Enterococcus faecium isolated from wood frogs: an emerging risk for zoonotic bacterial infections to humans. J Appl Microbiol. 2011;110(1):35-43.

32. Bresciano JC, Salvador CA, Paz-y-Miño C, Parody-Merino AM, Bosch J, Woodhams DC. Variation in the presence of anti-Batrachochytrium dendrobatidis bacteria of amphibians across life stages and elevations in Ecuador. EcoHealth. 2015;12(2):310-9.

33. Mauel MJ, Miller DL, Frazier KS, Hines ME. Bacterial pathogens isolated from cultured bullfrogs (Rana castesbeiana). J Vet Diagn Investig. 2002;14(2):431-3.

34. Campbell TW. Peripheral blood of amphibians. In: Campbell TW, editor. Exotic animal hematology and cytology. 4th ed. Ames: Wiley Blackwell; 2015. p. 89-95.

35. Campbell TW. Normal herptile (reptiles and amphibian) cytology. In: Campbell TW, editor. Exotic animal hematology and cytology. 4th ed. Ames: Wiley Blackwell; 2015. p. 229-33.

36. Mosier DA. Vascular disorders and thrombosis. In: Zachary JF, editor. Pathologic basis of veterinary disease. 6th ed. St. Louis: Elsevier; 2017. p. 44-72.

37. Gül Ç, Tosunoğlu M, Erdoğan D, Özdamar D. Changes in the blood composition of some anurans. Acta Herpetol. 2011;6(2):137-47.

38. Allender MC, Fry MM. Amphibian Hematology. Vet Clin N Am Exot Anim Pract. 2008;11(3):463-80.

39. Levin J. The evolution of mammalian platelets. In: Michelson AD, editor. Platelets. 4th ed. Amsterdam: Academic Press; 2019. p. 1-23.

40. Barni S, Boncompagni E, Grosso A, Bertone V, Freitas I, Fasola M, et al. Evaluation of Rana snk esculenta blood cell response to chemical stressors in the environment during the larval and adult phases. Aquat Toxicol. 2007;81(1):45-54

41. Mitchell JB. The effect of host age on Rana temporaria-Gorgoderina vitelliloba interactions. Int J Parasitol. 1982;12(6):601-4.

42. Li J, Barreda DR, Zhang YA, Boshra H, Gelman AE, LaPatra S, et al. B lymphocytes from early vertebrates have potent phagocytic and microbicidal abilities. Nat Immunol. 2006;7(10):1116-24.

43. Arikan $\mathrm{H}$, Çiçek K. Morphology of peripheral blood cells from various species of Turkish herpetofauna. Acta Herpetol. 2010;5(2):179-98.

44. Alleman AR. Abdominal, thoracic, and pericardial effusions. Vet Clin N Am Small Anim Pract. 2003;33(1):89-118.

45. Pessier AP. Amphibia. In: Terio KA, McAloose D, Leger JS, editors. Pathology of wildlife and zoo animals. London: Academic Press; 2018. p. 921-51.

\section{Publisher's Note}

Springer Nature remains neutral with regard to jurisdictional claims in published maps and institutional affiliations.
Ready to submit your research? Choose BMC and benefit from:

- fast, convenient online submission

- thorough peer review by experienced researchers in your field

- rapid publication on acceptance

- support for research data, including large and complex data types

- gold Open Access which fosters wider collaboration and increased citations

- maximum visibility for your research: over $100 \mathrm{M}$ website views per year

At BMC, research is always in progress.

Learn more biomedcentral.com/submissions 